\title{
INFLUENCE OF ULTRASONIC TREATMENT ON BARLEY GRAINS GERMINATION AS WELL AS PAN BREAD QUALITY
}

\author{
HAYAT H. ABD-ELSATTAR \\ Crops Tech. Res. Dep. Food Tech. Res. Inst., Agric. Res. Center, Giza, Egypt \\ (Manuscript received 12 April 2018)
}

\begin{abstract}
$\mathrm{T}$ he present investigation aimed to study the influence of ultrasonic treatment on the germination and a-amylase activity of barley grains (Giza 127 variety). All experiments have been performed at fixed frequency of $40 \mathrm{KHz}$ at different ultrasonic power $40,60,80$, and $100 \%$ of power setting device $(120 \mathrm{~W})$ for 5,10 and $15 \mathrm{~min}$ with constant temperature $\left(30^{\circ} \mathrm{C}\right)$. Germination percent and moisture content during different soaking periods ranged from ( 24 to $45 \mathrm{hr}$ ) were determined and the results showed that the moisture content of the barley grains increased by increasing soaking time. The germination percentage of the above mentioned treatments reached its maximum value under ( $40 \%$ power setting for 10 and $15 \mathrm{~min}$ ) during 1,3 and 7 days of germination which in parallel with the germination rate .Also, the results, showed that a good relation between a-amylase activity and germination rate .The chemical composition of the barley grains and its malt after sonication revealed increase in protein and fat and decrease in ash, crude fiber and carbohydrate contents compared with control. Pan bread prepared by using $1 \%$ sonicated malt resulted from ( $40 \%$ power setting for $10 \mathrm{~min}$ ) gave satisfactory results on the physical properties (volume, specific volume and density). The results cleared that sonicated barley affected all sensory attributes to show high significant increase compared with either raw materials or control. Meanwhile, it affected the malt and pan bread color. Texture profile of the resulted bread showed significant decrease in hardness, springiness and chewiness in all sonicated treatments. On contrast cohesiveness and Gumminess were significantly increased compared with control and raw materials.
\end{abstract}

Key words: ultrasonication, method, barley, germination , malt , pan bread.

\section{INTRODUCTION}

Barley is one of the major industrial grains of monocotyledonous grains, in the malting industry. The malt grain is used for the production of barley malt extract (powders and syrups) and diastase. Therefore improved yield and/or rate of barley germination would be valuable in the area of commercial brewing and agriculture. In addition, shortening the germination period may have significant commercial benefits to the brewing industry and reduce bacterial and fungal damage which may affect the yield (Yaldagard et al., 2008). Several techniques are used for controlled water uptake of barley grain including priming with an additive solution such as chemicals 
(Ajouri et al., 2004 ). Chemical methods have disadvantages if the malt contains residues due to the treatment. The ionization method, according to the work of Ress et al., (1987), is successfully applicable for malting barley grains within certain ranges, but there is a problem associated with this method. It is that the radiation treatment must be carried out in the starting stage of the processing; suitable germination of the treated barley should start within a week from irradiation, as the inductive effect of irradiation treatment tends to decline during storage. Considering the great importance of precious germination in malt quality, use of ultrasonication as a pretreatment may be a good technique to be tried along with normal steeping of barley. The application of ultrasound to biotechnological processes has recently attracted the attention of some research groups (Yaldagard et al., 2008). Utrasonication method is widely used for laboratory scale and it does not require sophisticated equipment or extensive technical training. The structure and function of biological molecules can be changed by the ultrasound technique. Ultrasound as a novel physical method acts as an alternative stress on cells or tissues. Besides the vast number of applications in chemical and applied industries, this technique has several emerging applications in the field of agriculture and food industry including carrot, radish, maize, barley, rice and sunflower (Yaldagard et al., 2008). In bakery products, diastase malts (containing active enzymes) are used as dough conditioners at very low levels (1-3\%), imparting a unique flavor and crumb color (Arendt \& Zannini, 2013 ). In the past barley malt was added in a small amount (often less than $1 \%$ ) to bakery products as a source of enzymes, leading to faster starch hydrolysis and better leavening of dough. As a result of starch hydrolysis a sufficient amount of fermentable sugars (mainly maltose and in small amount of low molecular weight dextrins) is obtained that can be further metabolized by yeast. lower dose of yeast can also be compensated by addition of malt flour, the principal functional benefits of the malt flour addition include an increased gas production in the dough, an improved crust color formation, a better crumb moisture retention, and an enhanced flavor development. (Iva HONCŮ et a/ 2015). Bread with a-amylase addition has higher volume, better crumb texture and coloration of the crust (Begić et al., 2014).

The objectives of this work are to study the ultrasound effects on barley germination as well as the influence of resulted malt addition on pan bread quality. 


\section{MATERIALS AND METHODS}

Materials: Hulled barley grain (variety Giza 127, 2 rows - normal- yield may 2017) was obtained from Barley Research Dept., Field Crop Res., Institute, Agric., Res. Center ,Giza, Egypt . To prevent absorption of moisture it was stored in a dry place at room temperature $\left(25 \pm 2{ }^{\circ} \mathrm{C}\right)$ until using. Wheat flour ( $72 \%$ extraction) was obtained from Five Stars Company, suez City, Egypt. Ingredients e .i. sugar (Sucrose), salt (Sodium cholorid), active dry yeast and corn oil were purchased from the local market .

Chemicals and Reagents: All chemical used in the present study were analytical grade and obtained from Sigma -Aldrich. and Fluka companies their addresses (Mawardy ,Cairo, Egypt and Gillingham ,England ,UK respectively).

Ultrasonic irradiation: was produced by a bench-top bath sonicator (3069 USC3, Rapid graph Inc., NJ, USA) with 120 watt Output, 40 kHz frequency, $220 \mathrm{~V} \pm 10 \mathrm{~V}, 50$ $60 \mathrm{~Hz}$ power supply and $176 \times 164 \times 100$ (height)mm tank dimensions. This instrument is found in (Field crops Res. Technology department, Food Technology Research Institute, Agricultural Research Center, Giza,Egypt).

Methods: In this study, four important effective parameters were used for sonication experimental design as shown in Table (1).

Table I . sonication experimental design.

\begin{tabular}{|lccccc|}
\hline \multicolumn{1}{|c}{ Factors } & Level 1 & Level $\mathbf{2}$ & Level 3 & level4 \\
\hline $\mathrm{P}(\%)$ & 40 & 60 & 80 & 100 \\
$\mathrm{t} \quad(\mathrm{min})$ & 5 & & 10 & 15 & - \\
temperature $\left({ }^{\circ} \mathrm{C}\right)$ & 30 & 30 & 30 & 30 & \\
frequency $(\mathrm{KHz})$ & 40 & 40 & 40 & 40 \\
\hline
\end{tabular}

P: Ultrasonic power setting(W). $\quad t$ : ultrasonic exposure time $(5,10$, and $15 \mathrm{~min})$.

Barley grain treatments: The ultrasonication experiments were carried out at 40 $\mathrm{kHz}$ on the ultrasonic generator according to(Goussous et al., 2010 ). All experiments were performed on samples (10 g barley grains) dispersed in $80 \mathrm{~mL}$ of tap water with direct sonication at a power input of $40,60,80$ and $100 \%$ of a device efficiency .The solution was processed at a constant temperature of $30^{\circ} \mathrm{C}$ with the sonication for 5,10 , and $15 \mathrm{~min}$. The temperature of water circulating in the water bath was set and the temperature inside the beaker ( $100 \mathrm{~mL}$ laboratory glass beaker) was checked intermittently, so that the temperature of the solution remained constant during the experiments. 
Germination and preparation of barley dried malt powder : After steeping at $16-17^{\circ} \mathrm{C}$ for $24 \mathrm{~h}$ in the incubator chamber germination. Sonicated grains were surface sterilized with $2 \%(\mathrm{v} / \mathrm{v})$ hydrogen peroxide followed by distilled water. Experiments and control were conducted at $\left(25 \pm 2^{\circ} \mathrm{C}\right)$ in $100 \mathrm{~mm}$ Petri dishes (30 grains per dish , 3 replicates) on a layer of filter paper, moistened with distilled water. Water was added to the Petri dish as needed. Grains were considered germinated when rootlets were noted at the edge of the grain. Germination counts and characterization of seedlings were made daily until germination ceased (7 days). The total number of germinated seeds to normal seedlings were evaluated from zero time until the end of test period according to the criteria of AOSA (1986) and expressed as germination percentage (GP). The malted samples were air dried and the drying process was stopped when the moisture content of samples reached $4 \%$ nearly 7-10 days (Osman 2002), removed shoots and rootlets, finely milled and sieved through (315 $\mu \mathrm{m}$ sieve -Fritsch aralysette, Type 03.502.No: 8210,Germany ) into powder The malted powder was backed into polyethylene bags till used (as improver) .

\section{a -amylase activity :-}

a- Extraction of enzyme from malt: In the present study $50 \mathrm{mM}$ sodium phosphate buffer with $\mathrm{pH}=8$ were used as the best extraction media. This buffer enhances the release of more enzymes rather than another media $0.75 \mathrm{~g}$ malt flour was weighed in duplicate into centrifuge tubes and $4 \mathrm{~mL}$ extraction media was added and mixing. Extraction was performed for $30 \mathrm{~min}$ at $30^{\circ} \mathrm{C}$ with regular vortexing for 5 $\mathrm{s}$ at $5 \mathrm{~min}$ intervals and was terminated by centrifugation for $10 \mathrm{~min}$ at $3000 \mathrm{xg}$. The supernatants were filtered through wet filter paper into measuring cylinders and the volumes were recorded. These volumes were used in the calculation of enzyme activities according to the method of (Osman, 2002).

b-Enzyme Assay: The progress of substrate hydrolysis was measured by determination of the reducing sugar equivalents released by using the modified 3,5dinitrosalicylic acid (DNS) assay following a $10 \mathrm{~min}$ fixed time incubation period with enzyme according to the method used for alpha-amylase assay by (Osman, 2002) ) and modified by (Gupta et al., 2003) with this difference that the optical densities of samples, controls and the standard were read at $540 \mathrm{~nm}$ using spectrometer lab . Med.,Inc. after cooling to room temperature and making up the contents of solution to $10 \mathrm{ml}$ with distilled water. Reducing equivalents were calculated from the calibration graph obtained by using absorbance data for standard solutions of maltose reacted with DNS as described. All enzyme assays were performed in 3 duplicate. One unit of alpha-amylase activity was defined as the quantity of enzyme that released the 
amount of reducing sugars equivalent per minute to one micromole of maltose, under the above defined assay conditions.

Preparation of pan bread: A straight dough bread making process was performed according to AACC (2002), basic dough formula was consisted of flour $(100 \mathrm{~g}), 1 \mathrm{~g}$ salt , active dry yeast $(4 \mathrm{~g}), 4 \mathrm{~g}$ sugar , the resulted malt improver (1g) add to all treatment except the raw one, corn oil $(10 \mathrm{~g})$, and the required amount of water was added.The dough was put into greased fermentation bowel and placed in a fermentation cabinet at $37^{\circ} \mathrm{C}$ and a relative humidity $80-85 \%$ for $20 \mathrm{~min}$ and then dough divided into pieces of $125 \mathrm{~g} \pm 0.2$. The dough was proofed for $35 \mathrm{~min}$ in a fermentation cabinet under controlled temperature and a relative humidity and then baked for $20 \mathrm{~min}$ at $240^{\circ} \mathrm{C}$ in an electric oven. Loaves were wetted with water from spray bottle. The pan bread was separated from the metal pans, left for cooling $2 \mathrm{hr}$ at room temp. The loaves volume and its weight were measured and sensory evaluation was done.

\section{Determination of steeped grains moisture content.}

Seed moisture content: (SMC) was determined for 10 seeds taken from each sample immediately after treatment. These seeds were blotted on a filter paper to remove excess water, weighed, oven dried at $105{ }^{\circ} \mathrm{C}$ for $72 \mathrm{~h}$ and then weighed again. Moisture contents of these seeds were estimated as percentages. (Goussous et al. 2010).

Analytical methods: Proximate Chemical Analysis of barley grains and pan bread (Moisture, crude protein, crude fat, crude fiber and ash were determined according to the methods (AOAC 2007). Carbohydrate were calculated (by difference).

Physical measurements of pan bread: Bread loaf weight $(\mathrm{g})$, volume $\left(\mathrm{cm}^{3}\right)$, Specific volume $\left(\mathrm{cm}^{3} / \mathrm{g}\right)$ and density $\left(\mathrm{g} / \mathrm{cm}^{3}\right)$ were determined according to the methods (AACC 2002).

Texture profile analysis (TPA) of Pan Bread: Bread texture i,e. Firmness (N), gumminess $(\mathrm{N})$, chewiness $(\mathrm{N})$, cohesiveness and springiness $(\mathrm{N})$ was determined by universal testing machine (Conetech, B type, Taiwan) provided with softwar according to (Bourne 2003).

Sensory evaluation of pan bread: Samples of pan bread were evaluated by 10 panelists (staff in Food Technology Research Institute, Agricultural Research Center, Giza,Egypt). Crust color (10), crumb color (20), taste (15), odor (15), texture (20) and general appearance (20) evaluated according to Kralmer and Twigg (1962). The total score of these sensory properties was calculated as overall acceptability . 
Color measurement of barley malt powder and pan bread crump samples. Color of barley malt powder and pan bread samples was measured according to the method outlined by Mc Gurie (1992) using a hand-held Chromameter (model CR-400, Konica Minolta, Japan).The apparatus provided L (lightness with $L=100$ for lightness, and $\mathrm{L}=$ zero for darkness), $\mathrm{a}$ (chromaticity on green $(-)$ to red $(+)]$, $\mathrm{b}$ (chromaticity on a blue $(-)$ to yellow $(+)]$.

Statistical analysis: For the analytical data, mean values and standard deviation are reported. The data obtained were subjected to one-way analysis of variance (ANOVA) at $P<0.05$. It was performed and the results were separated using the Multiple Range Duncan's test using the SAS (1987) statistical software.

\section{RESULTS AND DISCUSSION}

Moisture and germination percentage of barley grains: A laboratory experiment was conducted to determine the ordinary seed germination percentage (GP) during germination period and the moisture contents of barley grains after different steeping duration time ( $24,30,35,40$,and 45 hour) at room temperature $(25 \pm 2)^{\circ} \mathrm{C}$ was presented in Table (2).Significant differences were observed in both moisture and germination percentage after different soaking duration times .Increasing the soaking time, moisture content increased from (33.1 to $53.8 \%$ ) in relation to soaking time ( $24-45 \mathrm{hr}$ ). The germination percentage showed a values of $39,45.6$ and $49.6 \%$ after 1,3 and 7 days of soaking at moisture of $33.1 \%$. After 30 hr of steeping, a significant increase was $81.3,82.6$ and $93.6 \%$ at moisture content of $43.6 \%$.Increasing moisture content up to $46.4 \%$ resulted in decreasing germination percentage in parallel with soaking time. It showed a minimum germination at $53.8 \%$ moisture content and $45 \mathrm{hr}$ soaking time being 4,13 and $15 \%$ after 1,3 and 7 days, respectively.Treatments that soaked for 40 and $45 \mathrm{hr}$ removed due to the rotten of grains which resulted from the increasing both of moisture and soaking time. Soaking for $24 \mathrm{hr}$. which resulted the lowest germination percentage was selected to accelerate germination and to enhance the percentage of germination of barley grains through an ultrasonic priming technique. These results were in agreement with (Bryce et al., 2010) who reported that steeping time is one of the critical process influencing the modification of endosperm materials of barley malt , germination is generally achieved by steeping barley grains for $36-52 \mathrm{~h}$ to increase the moisture content of barley grains to about $45 \%$. 
Table 2. Moisture and germination (\%) of barley grains at different soaking period (hr).

\begin{tabular}{|c|l|l|l|l|}
\hline \multirow{2}{*}{$\begin{array}{c}\text { Soaking Time } \\
\text { (hour) }\end{array}$} & Moisture \% & \multicolumn{3}{|l|}{ germination (\%) } \\
\cline { 2 - 5 } & & $\mathrm{T} 1$ & $\mathrm{~T} 2$ & $\mathrm{~T}$ \\
\hline 24 & $33.10^{\mathrm{e}} \pm 0.05$ & $39.00^{\mathrm{c}} \pm 4.35$ & $45.60^{\mathrm{c}} \pm 7.76$ & $49.60^{\mathrm{c}} \pm 11.60$ \\
\hline 30 & $43.60^{\mathrm{d}} \pm 0.26$ & $81.30^{\mathrm{a}} \pm 6.11$ & $82.60^{\mathrm{a}} \pm 10.50$ & $93.60^{\mathrm{a}} \pm 10.06$ \\
\hline 35 & $46.40^{\mathrm{c}} \pm 1.14$ & $57.30^{\mathrm{b}} \pm 2.30$ & $66.60^{\mathrm{b}} \pm 0.001$ & $66.00^{\mathrm{b}} \pm 2.00$ \\
\hline 40 & $51.45^{\mathrm{a}} \pm 0.95$ & $16.00^{\mathrm{d}} \pm 0.001$ & $16.00^{\mathrm{d}} \pm 0.001$ & $17.50^{\mathrm{d}} \pm 19.00$ \\
\hline 45 & $53.80^{\mathrm{b}} \pm 0.38$ & $4.00^{\mathrm{f}} \pm 5.56$ & $13.00^{\mathrm{d}} \pm 16.10$ & $15.00^{\mathrm{d}} \pm 0.001$ \\
\hline L.S.D at 0.05 & 1.27 & 7.83 & 15.90 & 15.06 \\
\hline
\end{tabular}

$\mathrm{T} 1=$ first day of germination. $\mathrm{T} 2=$ third day of germination.T3= seventh day of germination.

$*$ Values are mean of three replicates $\pm S D$, number in the same column followed by the same letter are not significantly different at $(p \leq 0.05)$.

Moisture content of barley grains: Table (3): showed the effect of ultrasonic waves on moisture content of soaked barley grains at levels between 40 and 100\% power setting of the device (120W) during different time of sonication 5, 10 and 15 min). From the results it could observed that a significant increase was observed among all sonicated treatments compared with control (un treated sample). Generally , the moisture content was increased gradually by increasing power setting and exposure time of ultrasonic waves, moisture content was increased to $(38.98,41$ and $42.9 \%$ ) at $40 \%$ power setting, while at $100 \%$ power setting being (44.26, 46.7 and $50.9 \%$ ) at 5,10 , and 15 min exposed time respectively, compared to control ( un treated) which recorded $33.1 \%$ moisture content. From the obtained results it could be noticed that by using ultrasonic technique moisture content increased to 40 and $45 \%$ that suitable for barley germination processes. The sonication process accelerates the imbibitions of water through the pericarp (Yaldagard et al., 2008). In addition the same authors reported that ultrasonication produced numerous small holes in the coating and after steeping in the water a significant rise in seedling moisture resulted.

Table 3. Moisture percentage of soaking barley grains( 24 hour) exposed to different time duration of ultrasonic power setting compared with control (un treated).

\begin{tabular}{|c|c|c|c|c|c|}
\hline \multirow{2}{*}{$\begin{array}{l}\text { Time } \\
\text { (min) }\end{array}$} & \multirow[t]{2}{*}{ Power } & \multicolumn{4}{|c|}{ setting $(\%)$ of the device efficiency (120w) } \\
\hline & & $40 \%$ & $60 \%$ & $80 \%$ & $100 \%$ \\
\hline 5 & $33.1^{d} \pm 0.05$ & $38.98^{c} \pm 0.91$ & $42.23^{b} \pm 0.30$ & $43.28^{b} \pm 0.25$ & $44.26^{c} \pm .1 .50$ \\
\hline 10 & $33.1^{d} \pm 0.05$ & $41.00^{b} \pm 0.87$ & $43.45^{a} \pm 0.37$ & $44.51^{b} \pm .0 .38$ & $46.70^{b} \pm 0.22$ \\
\hline 15 & $33.1^{d} \pm 0.05$ & $42.90^{a} \pm 1.56$ & $44,90^{a} \pm 0.15$ & $46.60 \quad \mathrm{a} \pm 0.20$ & 50.90 a \pm 1.10 \\
\hline L.S.D at 0.05 & 1.66 & 1.16 & 1.70 & 1.19 & 1.98 \\
\hline
\end{tabular}

*Values are mean of three replicates $\pm S D$, number in the same column followed by the same letter are not significantly different at $(p \leq 0.05) .0 * *$, control treatment (un treated). 
Germination percentage and germination rate of soaked barley grains: Table (4) and Fig (1) revealed the germination percentage and the increasing germination rate of soaked barley grains treated with different ultrasonic power setting (40-100\%) of the device efficiency $(120 \mathrm{~W})$ at different exposure time ( $5-15 \mathrm{~min})$.The obtained data cleared non significant differences between all setting power $(40-100 \%)$ but showed highly significant increase compared with control (un treated) at ( $40 \%$ / 5 min ) .After 10 and $15 \mathrm{~min}$ and under $40 \%$ power setting, there are non significant differences in germination percentage and highly significant increase compared with control. At first day the highest germination percentage was (94.6) for (40\% /10 $\min$ ) , At third day the highest germination percentage was (94.6) for (40\% /10 min) followed by treatments ( $80 \%$ and $60 \% / 5 \mathrm{~min}$ ) which recorded $(94.4 \%$ and 94 $\%$ respectively .At 7-day, the values of germination percentage decreased significantly in ( 60,80 and $100 \%$ ) power setting at( $15 \mathrm{~min}$ ) exposure time .In Fig(1), the data showed that increasing germination rate (\%) of sonicated treatments relative to control (un treated one), the results revaluated that ,the germination rate decreased by increasing the germination time. A higher values in germination rate was observed at the first day of germination, where treatment (40\% / $10 \mathrm{~min}$ ) had the highest value (142\%).From the aforementioned data, it could be concluded that the pretreated soaked barley grains with ultrasonic for $10 \mathrm{~min}$ at $40 \%$ power setting was economically for time, power and germination percentage. Moreover, the soanicated barley absorbed water faster than the control, the steeping period was shortened to $24 \mathrm{hr}$. compared with the usual $45 \mathrm{hr}$ and during this time the barley seeds absorbed 41 to $45 \%$ of water necessary for germination, these results were in the line with those of (Yaldagard et al., 2008). These results may be attributed to mechanical effects due to ultrasonic treatment increasing water uptake by the cell walls. The method considerably reduced the time required to initiate the germination of seeds. Hair roots appeared faster in the treated samples and grew abundantly compared to the untreated grains. These results are also in agreement with Suslick ( 2001) who reported that, sonication will significantly reduce the mean germination time and will increase the rate and yield of germination. 
Table 4. Germination percentage of soaked barley grains (24hr) treated by different ultrasonic power setting at different exposure time(min) compared with control (un treated ).

\begin{tabular}{|c|c|c|c|c|c|c|c|c|c|c|c|c|c|c|c|}
\hline $\begin{array}{l}\text { Germination- } \\
\text { on time }\end{array}$ & \multicolumn{5}{|c|}{$\mathrm{T} 1$} & \multicolumn{5}{|c|}{$\mathrm{T} 2$} & \multicolumn{5}{|c|}{ T3 } \\
\hline $\begin{array}{c}\text { ** US } \\
\text { treatment }\end{array}$ & \multicolumn{15}{|c|}{ Germination percentage under Power setting (\%) of the device efficiency (120W) } \\
\hline $\begin{array}{l}\text { Duration } \\
\text { ( min) }\end{array}$ & $0 * * *$ & $40 \%$ & $60 \%$ & $80 \%$ & $100 \%$ & $0 * * *$ & $40 \%$ & $60 \%$ & $80 \%$ & $100 \%$ & $0 * * *$ & $40 \%$ & $60 \%$ & $80 \%$ & $100 \%$ \\
\hline 5 & $\begin{array}{l}39.0^{c} \\
\pm 4.35\end{array}$ & $\begin{array}{l}86.6^{a} \\
\pm 4.6\end{array}$ & $\begin{array}{l}91.3^{\mathrm{a}} \\
\pm 6.4\end{array}$ & $\begin{array}{l}93.3^{\mathrm{a}} \\
\pm 3.0\end{array}$ & $\begin{array}{l}76.6 \text { a } \\
\pm 8.3\end{array}$ & $\begin{array}{l}45.6^{c} \\
\pm 7.7^{\circ}\end{array}$ & $\begin{array}{l}88.0 \mathrm{a} \\
\pm 3.0\end{array}$ & $\begin{array}{l}94.0^{\mathrm{a}} \\
\pm 4.0\end{array}$ & $\begin{array}{l}94.4^{\mathrm{a}} \pm \\
3.9^{-}\end{array}$ & $\begin{array}{l}83.0^{a} \\
\pm 9.0\end{array}$ & $\begin{array}{l}49.6^{c} \\
\pm 11.6\end{array}$ & $\begin{array}{l}88.0^{\mathrm{a}} \\
\pm 4.0\end{array}$ & $\begin{array}{l}95.0^{\mathrm{a}} \pm \\
2.3\end{array}$ & $\begin{array}{l}94.0^{\mathrm{a}} \\
\pm 3.5\end{array}$ & $\begin{array}{l}85.0^{\mathrm{a}} \\
\pm 9.0\end{array}$ \\
\hline 10 & $\begin{array}{l}39.0^{c} \\
\pm 4.35\end{array}$ & $\begin{array}{l}94.6^{\mathrm{a}} \\
\pm 6.1\end{array}$ & $\begin{array}{l}66.6^{b} \\
\pm 8.0\end{array}$ & $\begin{array}{l}83.0^{a} \\
\pm 8.5\end{array}$ & $\begin{array}{l}71.6^{b} \\
\pm 16.5\end{array}$ & $\begin{array}{l}45.6^{c} \\
\pm 7.7^{\circ}\end{array}$ & $\begin{array}{l}94.6 \text { a } \\
\pm 6.1\end{array}$ & $\begin{array}{l}67.3^{b} \\
\pm 7.5\end{array}$ & $\begin{array}{l}85.6^{\mathrm{ab}} \\
\pm 9.7\end{array}$ & $\begin{array}{l}75.6^{b} \\
\pm 18.0\end{array}$ & $\begin{array}{l}49.6^{c} \\
\pm 11.6\end{array}$ & $\begin{array}{l}94.6 \text { a } \\
\pm 6.1\end{array}$ & $\begin{array}{l}69.3^{b} \\
\pm 8.0^{b}\end{array}$ & $\begin{array}{l}87.0^{\mathrm{a}} \\
\pm 11\end{array}$ & $\begin{array}{l}76.3 \text { ab } \\
\pm 18.5\end{array}$ \\
\hline 15 & $\begin{array}{l}39.0^{c} \\
\pm 4.35\end{array}$ & $\begin{array}{l}86.6^{a} \\
\pm 4.6\end{array}$ & $\begin{array}{l}50.3^{b} \\
\pm 10.5\end{array}$ & $\begin{array}{l}81.6 \text { ab } \\
\pm 7.5\end{array}$ & $\begin{array}{l}72.6^{b} \\
\pm 6.4\end{array}$ & $\begin{array}{l}45.6^{c} \\
\pm 7.7^{\circ}\end{array}$ & $\begin{array}{l}86.6^{\text {a }} \\
\pm 4.6\end{array}$ & $\begin{array}{l}61.0^{\mathrm{b}} \\
\pm 9.5\end{array}$ & $\begin{array}{l}79.0^{\mathrm{b}} \\
\pm 6.0^{\circ}\end{array}$ & $\begin{array}{l}75.3^{b} \\
\pm 8.0^{\circ}\end{array}$ & $\begin{array}{l}49.6^{c} \\
\pm 11.6\end{array}$ & $\begin{array}{l}89.3^{b} \\
\pm 3.0\end{array}$ & $\begin{array}{l}67.0 \text { ab } \\
\pm 6.0\end{array}$ & $\begin{array}{l}79 \text { ab } \\
\pm 6.0\end{array}$ & $\begin{array}{l}78.0^{\text {ab }} \\
\pm 8.0\end{array}$ \\
\hline L.S.D at 0.05 & 16.9 & 8.4 & 20.4 & 12.5 & 3.3 & 16.6 & 9.7 & 19.3 & 14.8 & 6.5 & 16.3 & 8.7 & 12.9 & 13.9 & 9.7 \\
\hline
\end{tabular}

$\mathrm{T} 1=$ First day of germination , $\mathrm{T} 2$ = third day of germination , $\mathrm{T} 3=$ seventh day of germination.

*Values are mean of three replicates $\pm S D$, number in the same column followed by the same letter are not significantly different at $(\mathrm{p} \leq 0.05))$. **Us=ultrasonic. $0^{* * *}$, control treatment (un treated) 


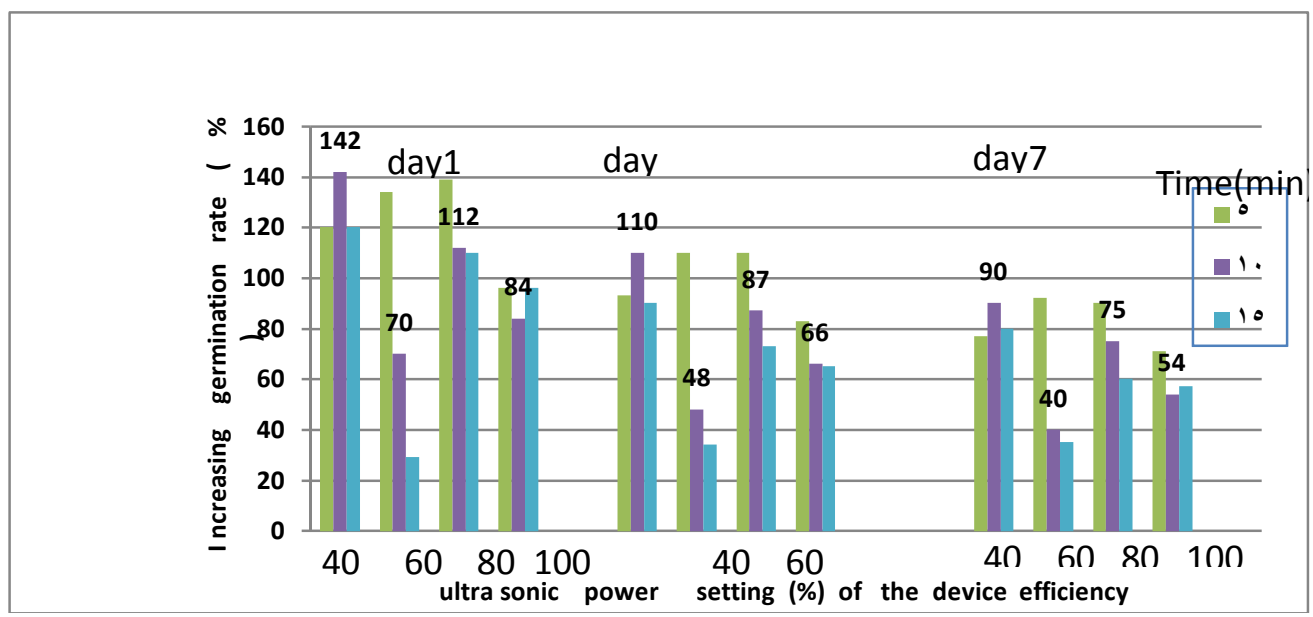

Fig. 1. The effect of ultrasonic treatment on the germination rate of barley grains .

The efficiency of ultrasonic stimulation on the alpha-amylase activity: The efficiency of ultrasonic stimulation on the germination of barley and alpha amylase activity was investigated at $30^{\circ} \mathrm{C}$ at levels between 40 and $100 \%$ power setting at 5, 10 and $15 \mathrm{~min}$. From the data illustrated in Fig (2) it could be observed that by using ultrasonic power, alpha-amylase activity will increase.All treated grains recorded a higher alpha-amylase activity compared with raw (barley powder) and control ( un treated ). The activity increased from $0.147 \mathrm{mg} / \mathrm{ml}$ and $0.42 \mathrm{mg} / \mathrm{ml}$ for raw and control ( un treated ) to reach the highest activity ( 1.15 and $1.122 \mathrm{mg} / \mathrm{ml}$ ) at $40 \%$ and $80 \%$ of power setting at 10 and 5 respectively. This increasing was about (7.8 and 7.63) and (2.7 and 2.67) times relative to raw and control treatments respectively. The other treatments were in the range of ( 0.629 to $0.955 \mathrm{mg} / \mathrm{ml}$ ) .these results are in agreement with Suslick, 1994) who reported that the reason for the increasing barley alpha-amylase activity may be due to the ultrasound stimulation, which caused more water retention before steeping and better germination after sonication of barley grains.

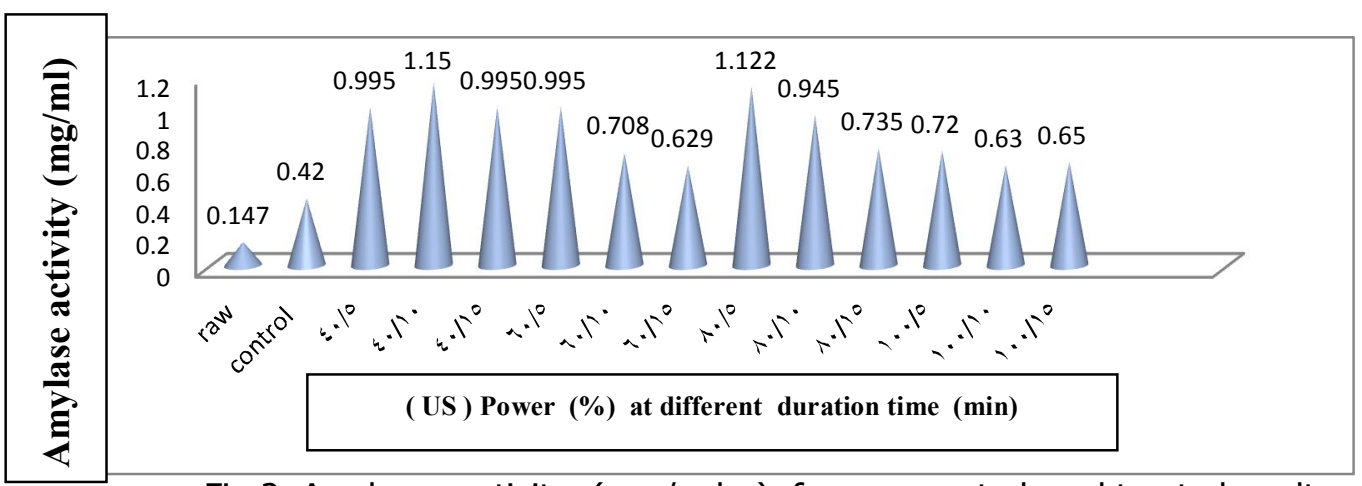

Fig 2. Amylase activity ( $\mathrm{mg} / \mathrm{ml}$ ) for raw, control and treated malt samples after one day $(24 \mathrm{hr})$ of germination. 
The Chemical compositions of barley grains and its' malt : Table (5) showed a significant $(p<0.05)$ variations in the proximate compositions of the barley powder (raw) ,control ( un treated ) and treated malt samples). Moisture ranged from 6.22 to $10.62 \%$, where the raw sample had the highest moisture content $(10.62 \%)$.A significant decrease was observed in control $(7.04 \%)$ and treated malt samples, where moisture content being $(6.22,6.85$ and $6.56 \%)$ for treated samples ( 40 , 60 and $80 \%$ ), respectively. It could be explained by the subsequent drying after germination in order to prevent the growth of microorganisms. Moreover rather similar results were reported by Erkan et al., (2006) who found that moisture in hulled barley flour ranged between10.7-11.8\%. Germinated barley flour(malt) Giza 126 recorded the lowest percentage of moisture content (4.4\%).It could be noticed from Table ( 5 ) that there was a significant increase in protein and fat content in all treated samples compared with the control.The highest protein and fat content was found in sonicated malt powder which was ranged from 10.1 to 10.47 and 3.0 to 3.24 compared with control (un treated ) and raw barley powder which recorded $\quad(9.60 \%$ and $9.28 \%$ ) and (2.8 and1.8\%)protein and fat content respectively. Concerning to ash content there were non significant differences between control and other samples except sample $(80 \% / 5 \mathrm{~min})$ showed significant increase in ash content $(1.73 \%)$. There were significant differences between control and treated samples in crude fiber content. It decreased significantly in all treated samples compared with control. Same trend was observed in carbohydrate content, the highest value was (83\%) for control sample. While the lowest value was $(82.01 \%)$ for $(80 \% / 5 \mathrm{~min})$. Similar results were recorded by (Erkan et al., 2006), who showed that protein content in hulled barley flour ranged between ( $8-10 \%)$. These results were agreement with Ereifej and Haddad (2001) who reported that , crude fiber, ash and carbohydrates ranged between $3.83-4.37 \%, 2.29-2.86 \%$ and $73.40-82.66 \%$ in raw and germinated barley (malt) respectively. The crude fiber content was higher in the hulled barley (3.7\%). 
Table 5. Moisture and Chemical composition of raw barley, control and selected treated malt samples (\% on dry weight basis ).

\begin{tabular}{|l|l|l|l|l|l|l|}
\hline **Treatment & Moisture & Protein & Fat & ash & fiber & Carbohydrate \\
\hline Raw & $10.62^{\mathrm{a}} \pm 0.25$ & $9.28^{\mathrm{d}} \pm 0.07$ & $1.80^{\mathrm{c}} \pm 0.08$ & $1.91^{\mathrm{a}} \pm 0.17$ & $3.50^{\mathrm{a}} \pm 0.43$ & $83.50^{\mathrm{a}} \pm 0.36$ \\
\hline Control $(0 \%)$ & $7.04^{\mathrm{b}} \pm 0.48$ & $9.60^{\mathrm{c}} \pm 0.02$ & $2.80^{\mathrm{a}} \pm 0.10$ & $1.46^{\mathrm{c}} \pm 0.40$ & $3.14^{\mathrm{b}} \pm 0.12$ & $83.00^{\mathrm{b}} \pm 0.27$ \\
\hline $40 \% / 10 \mathrm{~min}$ & $6.22^{\mathrm{c}} \pm 0.28$ & $10.47^{\mathrm{a}} \pm 0.1$ & $3.00^{\mathrm{a}} \pm 0.21$ & $1.44^{\mathrm{c}} \pm 0.02$ & $2.50^{\mathrm{c}} \pm 0.10$ & $82.59^{\mathrm{c}} \pm 0.17$ \\
\hline $60 \% / 5 \mathrm{~min}$ & $6.85^{\mathrm{b}} \pm 0.05$ & $10.10^{\mathrm{b}} \pm 0.1$ & $3.20^{\mathrm{a}} \pm 0.25$ & $1.49^{\mathrm{c}} \pm 0.08$ & $2.80^{\mathrm{bc}} \pm 0.27$ & $82.41^{\mathrm{cd}} \pm 0.89$ \\
\hline $80 \% / 5 \mathrm{~min}$ & $6.56^{\mathrm{bc}} \pm 0.32$ & $10.40^{\mathrm{a}} \pm 0.1$ & $3.24^{\mathrm{a}} \pm 0.15$ & $1.73^{\mathrm{b}} \pm 0.06$ & $2.60^{\mathrm{c}} \pm 0.20$ & $82.01^{\mathrm{d}} \pm 0.20$ \\
\hline L.S.D at 0.05 & 0.56 & 0.22 & 0.31 & 0.16 & 0.36 & 0.40 \\
\hline
\end{tabular}

*Values are mean of three replicates $\pm S D$, number in the same column followed by the same letter are not significantly different at $(p \leq 0.05))$.

**Treatments at first day of germination.

\section{Color measuring of dried malt powder and pan bread crumb samples: Color} is one of the most important indicators of bread quality. The desirable color should be (white to yellow) and creamy white for malt powder and bread crumb, respectively .From the data presented in Table ( 6 ) ,it could be noticed that ,L*values (lightness) generally showed a significant decrease in sonicated malt powder samples and showed non significant differences in pan bread crumb samples compared with their controls.The sonicated malt powder samples were darker (lower $L^{*}$ value ) than control. This variation may be due to the increase of germination percentage which caused the color darkness. The mean a*value, there was a significant increase in both of the two sonicated malt powder samples 40\%/10 min and $80 \%$ /5min, which recorded ( 0.91 and 0.80$)$ ) compared with control (0.47).On other hand, non significant differences between sonicated pan bread samples except (40\%/10 min) which recorded a significant increase (1.96) compared with control (1.55). The negative $a^{*}$ values in malt powder samples indicated the green color which may be due to the germination process, vise versa the positive a* values (red color) in pan bread crumb samples related to the effect of high baking temperature ( $240^{\circ} \mathrm{C}$ ). Concerning to the $b^{*}$ values( indicated the yellow color), non significant relation among all sonicated malt powder samples also among all pan bread samples compared with their s' controls. May be the addition of oil in pan bread ingredient causes the yellowish-colored. Esteller \& Lannes (2005) recorded $L^{*}, a^{*}$, and $b^{*}$ values were $62.37,1.14$, and 10.88 for the crumb of white breads, respectively. Also, the addition of malted barley powder with wheat flour for bakery 
making actually provides more protein for Maillard reaction to take place, which is normally encountered and desirable in baked goods. Moreover, the change in color might be due to nutrients interaction during processing and baking temperature and time combination.

Table 6. Color measuring of dried malt powder and pan bread crumb samples .

\begin{tabular}{|l|l|l|l|l|l|l|}
\hline \multirow{2}{*}{ Treatments*** } & \multicolumn{4}{|c|}{ Malt powder } & \multicolumn{3}{|c|}{ Pan bread crumb } \\
\cline { 2 - 7 } & $\mathrm{L}^{*}$ & $\mathrm{a}^{*}$ & $\mathrm{~b}^{*}$ & $\mathrm{~L}^{*}$ & $\mathrm{a}^{*}$ & $\mathrm{~b}^{*}$ \\
\hline Raw & $89.19^{\mathrm{a}} \pm 0.30$ & $-0.26^{\mathrm{c}} \pm 0.01$ & $12.40^{\mathrm{ab}} \pm 0.22$ & $79.56^{\mathrm{a}} \pm 2.79$ & $1.48^{\mathrm{c}} \pm 0.01$ & $20.26^{\mathrm{a}} \pm 0.25$ \\
\hline Control (0\%) & $89.00^{\mathrm{a}} \pm 0.20$ & $-0.47^{\mathrm{d}} \pm 0.01$ & $12.50^{\mathrm{a}} \pm 0.03$ & $77.03^{\mathrm{ab}} \pm 0.18$ & $1.55^{\mathrm{bc}} \pm 0.07$ & $19.60^{\mathrm{a}} \pm 0.01$ \\
\hline $40 \% / 10 \mathrm{~min}$ & $86.56^{\mathrm{c}} \pm 0.20$ & $-0.91^{\mathrm{a}} \pm 0.01$ & $12.60^{\mathrm{a}} \pm 0.20$ & $73.64^{\mathrm{b}} \pm 1.27$ & $1.96^{\mathrm{a}} \pm 0.07$ & $19.50^{\mathrm{a}} \pm 0.65$ \\
\hline $60 \% / 5 \mathrm{~min}$ & $88.50^{\mathrm{ab}} \pm 1.15$ & $-0.47^{\mathrm{d}} \pm 0.01$ & $12.35^{\mathrm{ab}} \pm 0.15$ & $76.59^{\mathrm{ab}} \pm 5.10$ & $1.55^{\mathrm{bc}} \pm 0.14$ & $19.40^{\mathrm{a}} \pm 1.15$ \\
\hline $80 \% / 5 \mathrm{~min}$ & $87.64^{\mathrm{b}} \pm 0.22$ & $-0.80^{\mathrm{b}} \pm 0.01$ & $12.32^{\mathrm{ab}} \pm 0.10$ & $76.30^{\mathrm{ab}} \pm 3.13$ & $1.72^{\mathrm{b}} \pm 0.19$ & $19.90^{\mathrm{a}} \pm 1.80$ \\
\hline L.S.D & $1.02^{2}$ & 0.08 & 0.28 & $5.49^{2}$ & 0.21 & 1.82 \\
\hline
\end{tabular}

$* \mathrm{~L}$ (lightness with $\mathrm{L}=100$ for lightness, and $\mathrm{L}=$ zero for darkness), $\mathrm{a}$ * [(chromaticity on a green $(-)$ to red $(+)], b^{*}[$ (chromaticity on a blue $(-)$ to yellow). $* *$ Values are mean of three replicates $\pm S D$, number in the same column followed by the same letter are not significantly different at $(p \leq 0.05))$.

***Treatments at first day of germination.

Sensory evaluation of pan bread: Sensory evaluation of pan bread samples at levels between $(0,40,60$ and80\%) setting power are shown in Table (7 ). The results showed that raw and control bread samples recorded the lowest scores for all attributes relative to other pan bread samples .A significant increase was found due to sonication treatment compared with control $(0 \%)$.The overall acceptability of treated samples was higher than the raw and the control samples. Sample (40\%/10min) had the highest overall acceptability (97.25\%) compared with the other two treated samples (60\%/5min and $80 \% / 5 \mathrm{~min})$ which recorded (95.15 and $95.4 \%)$ respectively. In addition, non significant differences were found in overall acceptability between samples while there were a significant increase between treated samples and control. In general, it could be observed that addition of resulted sonicated malt (1\%) and sonication technique at different power setting especially (40\%/10min), improved pan bread quality . Lower dose of yeast can also be compensated by addition of malt flour. Diastase malts (containing active enzymes) are used as dough conditioners at very low levels (1-3\%), imparting a unique flavor and crumb color (Arendt \& Zannini, 2013) . 
Table 7. Sensory evaluation of pan bread samples.

\begin{tabular}{|c|c|c|c|c|c|c|c|}
\hline **treatment & $\begin{array}{r}\text { Texture } \\
\text { (20) }\end{array}$ & $\begin{array}{l}\text { Crumb } \\
\text { (20) }\end{array}$ & $\begin{array}{l}\text { Crust } \\
\text { (10) }\end{array}$ & $\begin{array}{l}\text { Oder } \\
\text { (15) }\end{array}$ & $\begin{array}{l}\text { Taste } \\
\text { (15) }\end{array}$ & $\begin{array}{l}\text { G. appearance } \\
\text { (20) }\end{array}$ & $\begin{array}{l}\text { Overall-acceptability } \\
\text { (100) }\end{array}$ \\
\hline Raw & $15.4^{\mathrm{b}} \pm 1.70$ & $14.4^{c} \pm 1.50$ & $7.0^{c} \pm 1.15$ & $11.9^{c} \pm 0.99$ & $11.9^{b} \pm 0.99$ & $14.90^{c} \pm 1.37$ & $75.50^{c} \pm 4.14$ \\
\hline $40 \% / 10 \min$ & $19.2^{\mathrm{a}} \pm 1.13$ & $19.4^{\mathrm{a}} \pm 0.84$ & $9.5^{\mathrm{a}} \pm 0.74$ & $15.0^{\mathrm{a}} \pm 1.24$ & $14.5^{\mathrm{a}} \pm 0.70$ & $19.55^{\mathrm{a}} \pm 0.76$ & $97.25^{\mathrm{a}} \pm 1.80$ \\
\hline $60 \% / 5 \min$ & $18.9^{\mathrm{a}} \pm 1.10$ & $18.9^{\mathrm{a}} \pm 0.73$ & $9.4^{\mathrm{a}} \pm 0.52$ & $14.2^{\mathrm{ab}} \pm 1.50$ & $14.1^{\mathrm{a}} \pm 0.87$ & $19.05^{\mathrm{a}} \pm 0.68$ & $95.15^{\mathrm{a}} \pm 3.10$ \\
\hline
\end{tabular}

$*$ Values are mean of three replicates $\pm S D$, number in the same column followed by the same letter are not significantly different at $(p \leq 0.05))$

**Treatments at first day of germination. 
Physical Properties of pan bread : Physical attributes (loaf weight, loaf volume, specific volume and density) of pan bread samples are given in Table ( 8). From the results, it could be observed that no significant difference between control and other samples in bread loaf weight values and it was ranged between 112.03 and $112.49 \mathrm{~g}$ , while there were a significant differences between control loaf volume (cm3)and other treatments.Significant differences in loaf volume between all treated samples. The highest volume $(425 \mathrm{~cm} 3)$ was recorded for sample $(40 \% / 10$ min power sitting) compared with control $(350 \mathrm{~cm} 3)$ and other samples. Concerning to specific volume $(\mathrm{cm} 3 / \mathrm{g})$ results cleared that treatment $(40 \% / 10 \mathrm{~min})$ had the highest specific value $3.79 \mathrm{~cm} 3 / \mathrm{g}$ followed by $(80 \% / 5 \mathrm{~min})$ then $(60 \% / 5 \mathrm{~min})$ which recorded 3.64 and 3.26 , respectively compared with control treatments $(3.12 \mathrm{~cm} / \mathrm{g})$. On the contrary, density of treaded samples decrease significantly compared with control. The specific volume of pan bread with any addition of amylase enzyme of all sonicated samples was significantly higher $(p<0.05)$ than the raw (free malt) sample which in parallel with loaf volume. The higher loaf volume may be due to gas production. The presence of amylase enzyme (from sonicated barley) hydrolyzes the starch and oligosaccharides to dextrin, maltose and glucose .During fermentation, yeast used these products in producing $\mathrm{CO} 2$ which affected loaf volume (Kim et al., 2006).

Table 8. Physical properties of pan bread samples .

\begin{tabular}{|l|l|l|l|l|}
\hline **Treatments & \multicolumn{1}{|c|}{ Loaf weight $(\mathrm{g})$} & Loaf volume $(\mathrm{cm} 3)$ & \multicolumn{1}{|c|}{$\begin{array}{c}\text { Specific Volume } \\
(\mathrm{cm} 3 / \mathrm{g})\end{array}$} & \multicolumn{1}{|c|}{ Density $(\mathrm{g} / \mathrm{cm} 3)$} \\
\hline Raw & $112.05^{\mathrm{a}} \pm 1.90$ & $320.0^{\mathrm{e}} \pm 2.00$ & $2.85^{\mathrm{e}} \pm 0.020$ & $0.35^{\mathrm{a}} \pm 0.002$ \\
\hline Control $(0 \%)$ & $112.20^{\mathrm{a}} \pm 1.30$ & $350.0^{\mathrm{d}} \pm 1.00$ & $3.12^{\mathrm{d}} \pm 0.110$ & $0.32^{\mathrm{b}} \pm 0.010$ \\
\hline $40 \% / 10 \mathrm{~min}$ & $112.03^{\mathrm{a}} \pm 01.72$ & $425.0^{\mathrm{a}} \pm 2.00$ & $3.79^{\mathrm{a}} \pm 0.020$ & $0.26^{\mathrm{e}} \pm 0.015$ \\
\hline $60 \% / 5 \mathrm{~min}$ & $112.07^{\mathrm{a}} \pm 01.30$ & $365.6^{\mathrm{c}} \pm 1.00$ & $3.26^{\mathrm{c}} \pm 0.015$ & $0.31^{\mathrm{c}} \pm 0.002$ \\
\hline $80 \% / 5 \mathrm{~min}$ & $112.49^{\mathrm{a}} \pm 2.49$ & $410.0^{\mathrm{b}} \pm 0.9$ & $3.64^{\mathrm{b}} \pm 0.035$ & $0.27^{\mathrm{d}} \pm 0.003$ \\
\hline L.S.D & 0.500 & 2.698 & 0.099 & 0.008 \\
\hline
\end{tabular}

$*$ Values are mean of three replicates \pm SD, number in the same column followed by the same letter are not significantly different at $(p \leq 0.05))$.

**Treatments at first day of germination.

Texture profile analysis (TPA): Texture profile analysis (TPA) of pan bread samples included (hardness, cohesiveness, gumminess, chewiness and springiness) is shown in Table (9). The data revealed that a significant differences ( $p \leq 0.05$ between the TPA parameters among all pan bread samples .Raw and control samples revealed in hardness values of 8.64 and 8.6 ,respectively, which were significantly increased than those of treated ones $7.6,8.53$ and 8.5 for bread samples ( $40 \%$ setting for 10 $\min , 60 \%$ for $5 \mathrm{~min}$ and $80 \%$ for $5 \mathrm{~min}$ ), respectively. Cohesiveness, resulted in opposite trend than hardness which showed a significant decrease $(0.75,0.68$ and 
0.69 ).Gumminess showed that $80 \%$ setting for 5 min and $40 \%$ for 10 min produced pan bread with highest gumminess value (5.87) and (5.9) which was significantly increased than the other treatments. Chewiness and springiness showed a significant increase for raw and control samples compared with the treated treatments.The analysis of hardness indicated that a significant increase was observed in raw pan bread made with barley powder (without malt adding ) were considerable harder in comparison to sonicated resulted malt samples, where by increasing the germination rate and amylase activity ,hardness will be decrease , gumminess and cohesiveness increase may be due to the increase in crude fiber in free malt pan bread (raw ) and the hydrolysis of non-starch polysaccharides during germination . Raw bread formulation resulted in bread with harder crumb $(8.64 \mathrm{~N})$ and less cohesiveness $(0.64)$ and less gumminess $(5.55 \mathrm{~N})$ as compared to that of germinated barley malt powder samples which the cohesiveness ranged from(0.68 to 0.75$)$. These findings are in agree with (Ahmad et al., 2013). The decrease in the crumb firmness can be explained by the increase in the loaf volume as well as the improvement in the crumb characteristics. On other words, the increased loaf volume is directly related to decrease hardness values (table 8 \&9), fig ( 3 ) These results were in agreement by ( Yamsaengsung et al. 2010 ), they reported that cohesiveness in bread samples increased with the addition of barley malt than those of the raw and the control .

Table 9. Texture profile analysis (TPA) of pan bread.

\begin{tabular}{|l|l|l|l|l|l|}
\hline **Treatments & Hardness(N) & Cohesiveness & Gumminess (N) & Chewiness ( N) & Springiness(N) \\
\hline Raw & $8.64^{\mathrm{a}} \pm 0.77$ & $0.64^{\mathrm{b}} \pm 0.02$ & $5.55^{\mathrm{cd}} \pm 0.87$ & $26.32^{\mathrm{a}} \pm 0.20$ & $4.76^{\mathrm{a}} \pm 0.04$ \\
\hline Control $(0 \%)$ & $8.60^{\mathrm{a}} \pm 0.04$ & $0.65^{\mathrm{b}} \pm 0.03$ & $5.59^{\mathrm{c}} \pm 0.75$ & $26.38^{\mathrm{a}} \pm 0.80$ & $4.72^{\mathrm{a}} \pm 0.02$ \\
\hline$* 40 \% / 10 \mathrm{~min}$ & $7.60^{\mathrm{c}} \pm 0.46$ & $0.75^{\mathrm{a}} \pm 1.02$ & $5.90^{\mathrm{a}} \pm 0.99$ & $25.96^{\mathrm{b}} \pm 0.80$ & $4.40^{\mathrm{b}} \pm 0.07$ \\
\hline$* 60 \% / 5 \mathrm{~min}$ & $8.53^{\mathrm{b}} \pm 0.65$ & $0.68^{\mathrm{a}} \pm 0.02$ & $5.80^{\mathrm{b}} \pm 1.30$ & $25.81^{\mathrm{b}} \pm 0.80$ & $4.45^{\mathrm{b}} \pm 0.06$ \\
\hline$* 80 \% / 5 \mathrm{~min}$ & $8.50^{\mathrm{b}} \pm 0.42$ & $0.69^{\mathrm{a}} \pm 0.01$ & $5.87^{\mathrm{a}} \pm 1.01$ & $25.76^{\mathrm{b}} \pm 0.01$ & $4.39^{\mathrm{b}} \pm 0.07$ \\
\hline L.S.D & 0.07 & $0.09^{2}$ & 0.07 & $0.30^{-}$ & 0.07 \\
\hline
\end{tabular}

*Treatments at first day of germination.

$*$ Values are mean of three replicates $\pm S D$, number in the same column followed by then same letter are not significantly different at $(p \leq 0.05)$. 


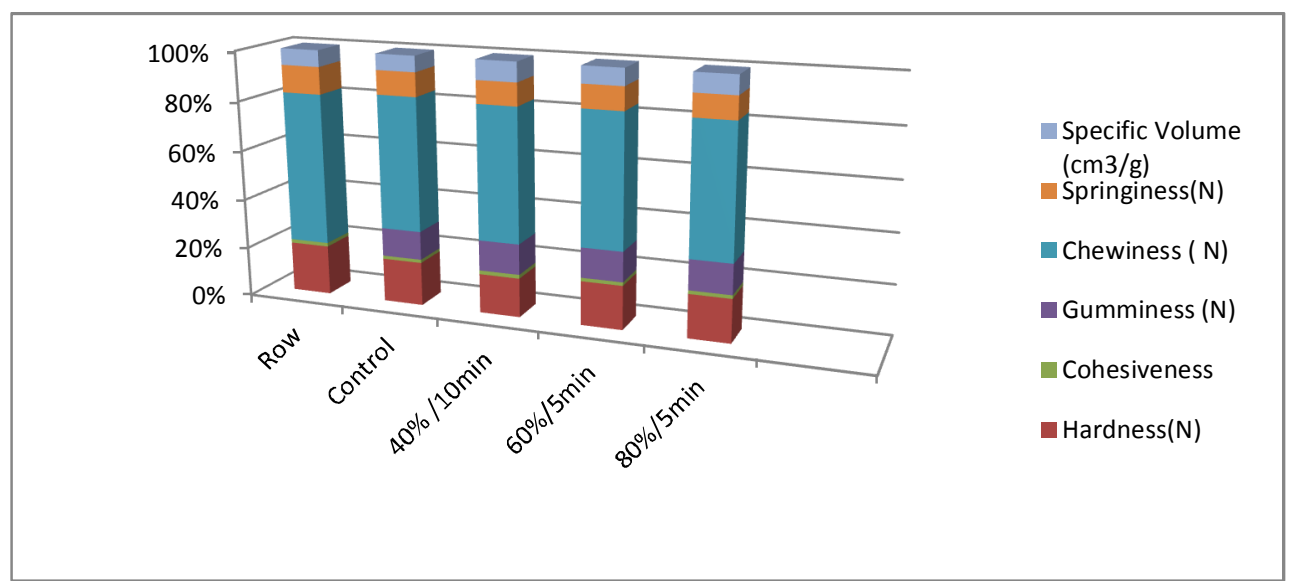

Fig 3. Texture profile parameters and specific volume of pan bread samples

\section{CONCLUSION}

From the obtained data it could be concluded that the ultrasonic treatment affected on the barley germination, where the germination period is shortened depending on level and exposure time to ultrasonic waves. Also increased barley alpha-amylase activity and caused more water retention and better germination after sonication of barley grains. The reduction in germination period was positively related to the moisture content and a-amylase activity. The best treatment was $40 \%$ power setting for $10 \mathrm{~min}$.The resulted malt can be used as bread improver, where it produced a good pan bread quality. In addition, this work recommended that, ultrasonication can be used as a novel method in the food industry, stimulated seed germination and increased the percentage of germination and the possibility of increasing productivity for large scale farm crops .

\section{REFERANCE}

1. AACC, 2002. Approved Methods of the American Association of Cereal Chemistry. Am. Assoc. Cereal Chem. Inc, St. Paul, Minnesota.

2. Ahmad, Z.; Butt, M. S.; Ahmed, A. and Khalid, N. 2013. Xylanolytic modification in wheat flour and its effect on dough rheological characteristics and bread quality attributes. Journal of the Korean Society for Applied Biological Chemistry, 56: 723-729

3. Ajouri, A. ; Asgedom, H. and Becker, M. 2004. Seed priming enhances germination and seedling growth of barley under conditions of $\mathrm{P}$ and $\mathrm{Zn}$ deficiency. J. Plant Nutrition and Soil Sci., 167(5), 630-636

4. AOAC. 2007. Association of Official Analytical Chemists. Official methods of analysis (18th ed.). Washington, DC. USA. 
5. AOSA . 1986. Association of Official Seed AnalysisRules for testing seeds. Journal of Seed Technology 6: 1-125.

6. Arendt ,K. E. and Zannini E. 2013. Barley, Cereal Grains for the Food and Beverage Industries. Woodhead Publishing Limited, Cambridge: 155-200,201

7. Begić ,M. ;Smajić M. and Oručević S. 2014. Ispitivanje kvaliteta hljeba u odnosu na dodatak sladnok brašna.Radovi Poljoprivredno-prehrambenok fakulteta, $58: 115-125$.

8. Bourne, M.C. 2003. Food Texture and Viscosity:Concept and Measurement. Elsevier Press, NewYork/London.

9. Bryce, J. H., Goodfellow, V., Agu, R. C., Brosnan, J. M., Bringhurst, T. A., \& Jack, F. R. 2010. Effect of Different Steeping Conditions on Endosperm Modification and Quality of Distilling Malt.Journal of the Institute of Brewing, 116(2), 125-133.

10. Ereifej K. I. and Haddad S.G. 2001. Chemical composition of selected jordanian cereals and legumes as compared with the FAO, Moroccan, East Asian and Latin American tables for use in the Middle East. Trends in Food Sci and Technol 11: 374-378 .

11. Erkan, H. ; Celik S. ; Bilgi B. and Koksel H. 2006. A new approach for the utilization of barley in food products: barley tarhana. Food Chem 97: 12-18

12. Esteller, M. S. \& Lannes, S. C. S. 2005. Parametros complementares para fixacao de identidade e qualidade de produtos panificados.Ciência e Tecnologia de Alimentos, 25(4), 802-806

13. Goussous,J. ; Samarah,N.H.; Alqudah,A.M. and Othman,M.O. 2010. Inhancing seed germination of flour crop spesies using an ultrasonic technique. . Expl Agric. , volume 46 (2), pp. 231-242 C _ Cambridge University Press 2010

14. Gupta ,R; Gigras, P,; Mohapatra, H.; Kumar G.V.and Chauhan B. 2003. Microbial alpha-amylases: a biotechnological perspective. Process Biochem., 38: 15991616.

15. Iva ,H. ;Lucie,K. ; Josef,P and Marcela,S. 2015. The effect of addition of malt flour on the dough, volume and sensory properties of bread. Paripex - Indian Jou. of Research. Issue : 9 |(4)152-155

16. Kim, J. H.; Maeda, T. and Morita, N. 2006. Effect of fungal a-amylase on the dough properties and bread quality of wheat flour substituted with polished flours. Food Research International, 39:117-126

17. Kralmer, A. and Twigg , B.A. 1962. Fundamentals of quality control for the food industry .AVI publishing Co . West port ,C.T.PP.512.

18. McGurie, R.G. 1992. Reporting of Objective Color Measurements. HortScience, $27,1254-1255$. 
19. Osman, A. M., 2002. The advantages of using natural substrate-based methods in assessing the roles and synergistic and competitive intractions of barley malt starch-degrading enzymes", J. Inst. Brew. 108(2), 204-214.

20. Ress, P.; Kiss, I.; Miltenyi, G.; Strahl, A.; Petro, I.; Farkas, J.; Biacs, P.; Kozma, I. and Debreczeny, I., 1987. Process for controlling the germination of malting barley, US Patent No.4,670,279.

21. SAS. 1987. Statistical analysis system. Release 6.03. SAS Institute Inc. Carry, Nc. USA.

22. Suslick KS. 1994. The chemistry of ultrasound. Encyclopeadia, Britannica, Chicago. pp. 138-155

23. Suslick, K.S., 2001. Sonoluminescence and Sonochemistry, Encyclopedia of Physical Science and Technology, 3rd edition, R. A. Meyers, Ed., Academic Press: San Diego. 17 : 363-376

24. Yaldagard, M.; Mortazavi, S. A. and Tabatabaie, F. 2008. Application of ultrasonic waves as a priming technique for accelerating and enhancing the germination of barley seed: Optimization of method by the Taguchi approach. Journal of the Institute of Brewing 114: 14-21

25. Yamsaengsung R., Schoenlechner R., Berghofer E. 2010. The effects of chickpea on the functional properties of white and whole wheat bread. International Journal of Food Science and Technology, 45: 610-620. 


\title{
تأثير الموجات فوق الصوتية على انبات الشعير و جودة خبز القو الب
}

\author{
حياة هاشم عبد الستار زيدان
}

قسم بحوث نكنولوجيا المحاصيل - معهُ بحوث تكنولوجيا الاغذية- مركز البحوث الزراعية - الجيزة - مصر

تهدف الدراسة الى دراسة تأثثر الموجات فوق الصوتية على معدل الانبات ونشاط انزيم

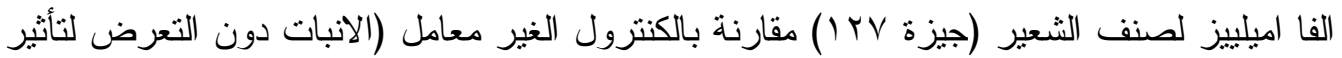

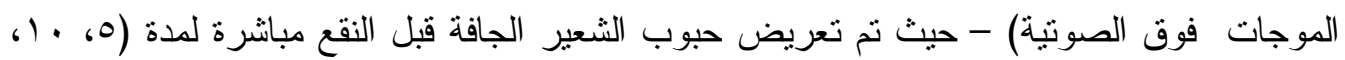

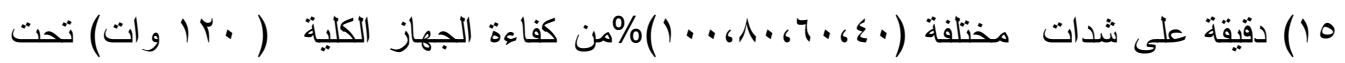

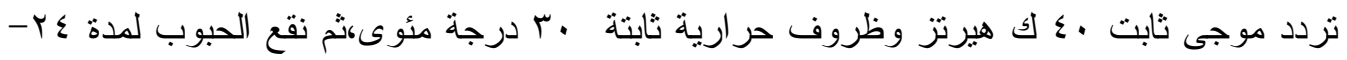

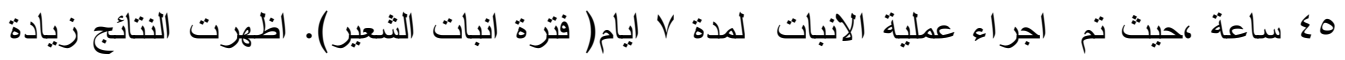

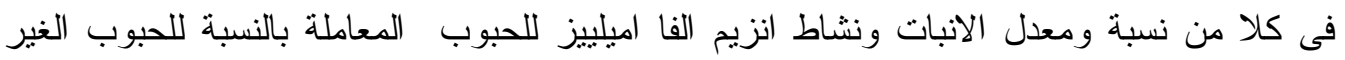

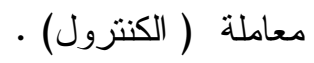

اوضحت النتائج ان بزيادة فترة نقع الحبوب تزداد نسبة الرطوبة ،كما اظهرت النتائج ان

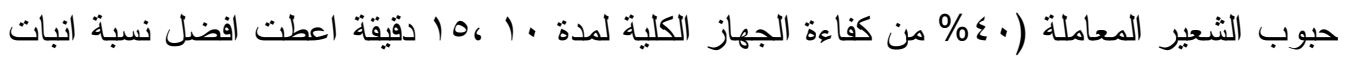

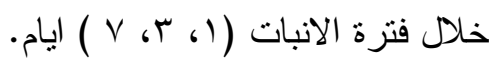

و اظهرت النتائج المتحصل عليها ايضا وجود علاقة قوية بين نشاط الالفا اميليزومعدل

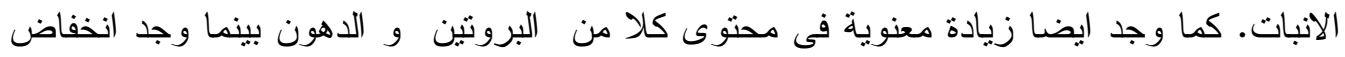

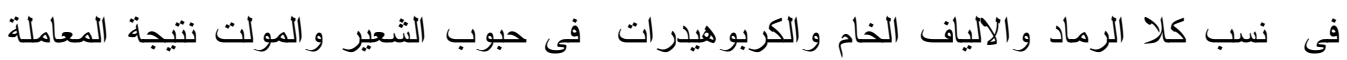

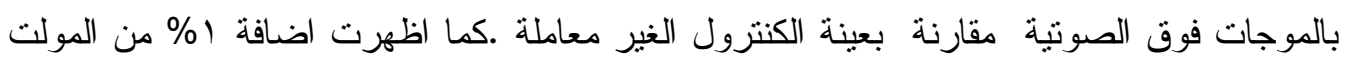

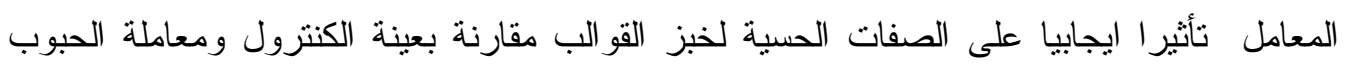
الجافة (الخام).

كما اوضحت النتائج المتحصل عليها انة لا يوجد فروق معنوية فى وزن الخبز نتيجة اضافة المولت المعامل ، بينما المعاملة (•ـ\% من كفاءة الجهاز • (دقيقة ) اعطت نتائج مرضية بالنسبة للخو اص الفيزيائية ( الحجم و الكثافة و الحجم النوعى) لخبز القو الب مقارنة بباقى المعاملات

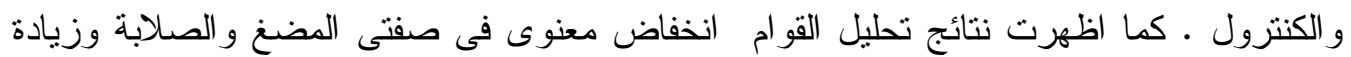
معنوية فى صفتى التماسك الالتصاق لخبز القو الب المنتج باضافة مولت الحبوب المعاملة بالنسبة لمولت الحبوب الغير معاملة (الكنترول) ودقيق حبوب الثعبر الجافة. 